\title{
Perbedaan kepuasan konsumen mahasiswa-mahasiswi Program Studi Psikologi Universitas Udayana terhadap pelayanan online store
}

\author{
Novia Imelda Yuslina Damanik dan Supriyadi \\ Program Studi Sarjana Psikologi, Fakultas Kedokteran, Universitas Udayana \\ paupasli@yahoo.com
}

\begin{abstract}
Abstrak
Berbelanja merupakan salah satu cara manusia untuk memenuhi kebutuhan hidupnya. Kebutuhan setiap manusia berbeda-beda, baik dari usia, jenis kelamin, sosial ekonomi dan juga status. Dalam memenuhi kebutuhan tersebut, manusia memerlukan interaksi dengan orang lain, salah satunya melalui kegiatan jual beli. Kegiatan jual beli pada mulanya hanya dapat berjalan apabila dilakukan secara konvensional, yaitu dengan tatap muka. Di era globalisasi, teknologi internet dapat menjadi media penjual dan pembeli melakukan kegiatan jual beli tanpa harus bertemu di suatu tempat atau toko. Perubahan proses ini mendorong masyarakat, dimana tidak hanya konsumen perempuan yang memiliki kebiasaan berbelanja online, tetapi juga mendorong konsumen laki-laki untuk berbelanja online. Mahasiswa dan mahasiswi lebih banyak menggunakan online store untuk berbelanja karena transaksi yang cepat dan hemat waktu. Konsumen mahasiswa maupun mahasiswi yang pernah belanja online memiliki pengalaman pelayan yang berbeda-beda dan faktor yang dapat mempertahankan perilaku belanja online tersebut adalah faktor kepuasan. Pengalaman pelayanan yang paling melekat dalam belanja online biasanya berupa ketanggapan, kecepatan, profesionalisme, dari admin online store dalam melayani konsumen. Penelitian ini bertujuan untuk mengetahui perbedaan kepuasan kosumen mahasiswa dan mahasiswi terhadap pelayanan online store. Subjek yang digunakan pada penelitian ini adalah mahasiswa dan mahasiswi Program Studi Psikologi Faktultas Kedokteran Universitas Udayana. Subjek total berjumlah 63 orang, yang terdiri dari 11 orang laki-laki dan 52 orang perempuan. Instrumen yang digunakan pada penelitian ini adalah skala kepuasan konsumen dengan koefisien reliabilitas sebesar 0.966. Hasil uji analisis T-test, menunjukkan nilai $p$ sebesar $0.142>0.05$, dengan demikian Ha ditolak, yang artinya tidak terdapat perbedaan kepuasan antara konsumen mahasiswa dengan mahasiswi terhadap pelayanan online store.
\end{abstract}

Kata kunci: Kepuasan konsumen, mahasiswa, mahasiswi, pelayanan online store.

\begin{abstract}
Shopping is one way to fulfill the needs of human life. The needs of every human being vary, based on age, gender, socioeconomic status, and others. In fulfilling these needs, people must interact with others, trading activity is one of them. A trading activitiy initially only happened if did conventionally. In the era of globalization, internet technology can help the sellers and buyers to do their activities without meet directly. These process encourage woman as an active shoppers, and it also encourages men to shop. Students and coeds used to go to online store for a fast transaction and save more times. Student and coed as consumers have so many different service experiences. The main factor that can mantain their online shopping behavior is satisfaction. The most inherent service experience in online shopping is usually formed by the responsiveness, speed, and professionalism of the admin of the online store in serving consumers. This study aims to determine the differences of students and coeds consumer satisfaction to online store services. The subjects of this study were students of the Departement of Psychology, Medical Faculty, Udayana University. The number of subject in this study were 63 student, consist of 11 students and 52 coeds. The instrument of this study is the customer satisfaction scale with reliability coefficient of 0.966 . The result of T-test analysis shows $p$ value is $0.142>0.05$, thus Ha is unaccepted, which means there is no difference of consumer satisfaction between students and coeds to online store service.
\end{abstract}

Keywords: Coeds, consumer satisfaction, online store service, students. 


\section{LATAR BELAKANG}

Perkembangan yang pesat dari internet ikut berperan membantu dalam hal berkomunikasi, saling berbagi informasi dan juga dalam hal berbelanja. Saat ini orangorang tidak perlu bersusah payah keluar rumah untuk pergi berbelanja kebutuhan di swalayan, pasar, butik, ataupun toko karena semua itu dapat dilakukan dirumah melalui internet. Berbelanja melalui internet memungkinkan konsumen untuk melihat terlebih dahulu produk atau jasa yang dijual oleh penjual melalui web yang telah disediakan dan dapat diakses dengan menggunakan media komputer, laptop, ataupun handphone yang tersambung ke layanan internet. Konsumen tidak harus bertatap muka secara langsung dengan penjual sehingga memberikan keuntungan bagi konsumen untuk mengakses berbagai situs web yang menyediakan kebutuhan dan keperluan konsumen dari seluruh dunia.

Penelitian yang dilakukan oleh Kresdianto (2014) pada mahasiswa di Fakultas Psikologi UIN Malang, menemukan bahwa mahasiswa merupakan pelaku belanja online dengan minat yang tinggi terkait dengan perkembangan gaya hidupnya. Mahasiswa yang dapat digolongkan ke dalam kelompok remaja akhir yang berada pada rentang usia 18 sampai 22 tahun dan sekaligus berada pada masa transisi menuju fase dewasa (Santrock, 2003). Sebagai salah satu bentuk kepuasan remaja sebagai mahasiswa adalah keinginan untuk memperlihatkan eksistensinya dengan melakukan segala cara, seperti mengunjungi pusat-pusat perbelanjaan seperti mall, butik, dan pusat perbelanjaan.

Kegiatan berbelanja di mall yang dilakukan oleh mahasiswa juga berdampak pada kegiatan berbelanja pada media online dimana mahasiswa merupakan konsumen terbanyak yang melakukan belanja online. Umumnya mahasiswa melakukan belanja online bukan didasarkan pada kebutuhan semata, tetapi demi kesenangan dan gaya hidup sehingga menyebabkan seseorang menjadi boros atau volume konsumsi yang melebihi kebutuhan sebenarnya (Sangadji dan Sopiah, 2013). Cara belanja yang diakui oleh konsumen itu menjadi salah satu kelebihan dan kekurangan yang dimiliki oleh online store karena cara belanja yang praktis dapat meminimalisir konsumen mengetahui produk aslinya. Penelitian terdahulu yang dilakukan oleh Rahma, Verina, dan Hariyanto (2012) menyatakan bahwa konsumen yang berbelanja online adalah konsumen yang dimudahkan proses jual belinya, karena semua transaksi yang dilakukan melalui media elektronik tanpa harus bertatap muka dengan penjual.

Kegiatan belanja online atau online shopping merupakan kegiatan dimana pembeli dan penjual tidak bertemu secara langsung seperti halnya proses penjualan biasa. Efisiensi waktu dan juga efektifitas dalam proses transaksi merupakan hal yang membuat konsumen tertarik untuk melakukan belanja online. Penjual akan menggunakan internet untuk menampilkan situs yang mereka miliki sebagai toko dengan segala produk yang ditawarkan kepada konsumen.
Wade dan Tavris (2007) menyatakan bahwa jenis kelamin merupakan atribut fisiologis dan anatomis yang membedakan antara laki-laki dan perempuan. Sejalan dengan pengertian tersebut, Hungu (2007) juga mendefinisikan jenis kelamin adalah pembeda antara lakilaki dan perempuan secara biologis dan sudah ada sejak lahir. Perbedaan dan fungsi biologis tersebut tidak dapat ditukar dan fungsinya akan tetap menempel dengan jenis kelaminnya masing-masing. Perbedaan dari penampilan, sikap, dan kepribadian merupakan faktor yang membentuk peran jenis kelamin dalam kehidupan sehari-hari. Jenis kelamin merupakan faktor yang mempengaruhi dalam berbelanja online. Jenis kelamin adalah perbedaan bentuk, sifat dan fungsi biologis, termasuk di dalamnya pembagian peran kedudukan antara laki-laki dan perempuan ditetapkan oleh masyarakat.

Menurut Solomon (2011) perilaku konsumen laki-laki dan perempuan mengikui teori Freud yang mengatakan bahwa tiap-tiap konsumen secara sadar dan tidak sadar memiliki motivasi intrinsik yang mengarahkan dirinya untuk berbelanja. Keputusan berbelanja online dilakukan hanya untuk membeli barang tertentu walaupun tidak spesifik diketahui motivasi membelinya. Perdebatan id, ego, dan superego sering terjadi ketika berbelanja, seperti membeli sesuatu padahal tidak membutuhkan atau sebaliknya butuh tetapi tidak dibeli. Konsumen perempuan dinyatakan cenderung mengalami hal ini dari pada konsumen laki-laki, sehingga perilaku belanja online konsumen laki-laki dan perempuan pun dapat dikatakan berbeda.

Sangadji dan Sopiah (2003) menyatakan bahwa konsumen memiliki beberapa subbudaya yang membagi-bagi karakteristik konsumen, seperti usia, agama, kelas sosial, jenis kelamin, etnis, dan regional. Karakteristik usia dapat terdiri dari kelompok usia anak dan remaja, kelompok usia baby boomer, dan kelompok usia dewasa. Mahasiswa dan mahasiswi termasuk pada kelompok subbudaya usia remaja. Kelompok ini sudah mampu mengakses informasi melalui internet dengan lancar. Oleh karena itu, mahasiswa akan selalu menjadi sasaran pemasaran yang menggunakan teknologi tinggi. Karakteristik jenis kelamin dalam pemasaran online juga mengambil bagian dalam subbudaya usia remaja, atau yang sering dibedakan menjadi mahasiswa dan mahasiswi.

Konsumen sebagai mahasiswa maupun mahasiswi yang pernah belanja online memiliki pengalaman pelayanan yang berbeda-beda dan faktor yang dapat mempertahankan perilaku belanja online tersebut adalah faktor kepuasan. Pengalaman pelayanan yang paling melekat dalam belanja online biasanya berupa ketanggapan, kecepatan, profesionalisme, admin online store dalam melayani konsumen (Berata, 2015). Apabila pengalaman konsumen secara keseluruhan dapat terjadi seperti ekspektasi, maka kepuasan dapat tercapai. Menurut Kotler (1993), kepuasan konsumen merupakan hasil dari apa yang dirasakan oleh konsumen sesuai dengan harapannya. Konsumen merasa 
puas apabila harapannya terpenuhi dan konsumen akan merasa bahagia apabila produk tersebut melampaui harapannya. Konsumen yang puas akan lebih setia pada produk maupun produsen, membeli lebih banyak, menoleransi harga dan akan menguntungkan produsen. Untuk menciptakan kepuasan konsumen, produsen sebaiknya mampu menghasilkan produk yang bermanfaat bagi sebagian besar target konsumennya (dalam Solomon, 2011).

Penelitian yang dilakukan oleh Yulianti (dalam Hakim, 2016) tentang kepuasan konsumen mahasiswa dan mahasiswi menunjukkan hasil penelitian bahwa konsumen mahasiswa lebih merasa puas apabila dibandingkan dengan konsumen mahasiswi. Dengan persentase rata-rata tingkat kepuasan yang dirasakan konsumen mahasiswa sebesar $(43.43 \%)$ sedangkan konsumen mahasiswi sebesar $(42.33 \%)$, sehingga terdapat perbedaan kepuasan konsumen mahasiswa dan konsumen mahasiswi tersebut dalam berbelanja online.

Hal ini berbanding terbalik dengan penelitian Hakim (2016) yang menyatakan bahwa konsumen perempuan yang tingkat kepuasannya tinggi yang lebih banyak dengan persentase (57,14\%) sedangkan konsumen laki-laki hanya (50\%). Dalam beberapa penelitian yang pernah dilakukan, terdapat perbedaan kepuasan dalam persentase konsumen laki-laki dan perempuan, walaupun salah satu penelitian menyatakan bahwa konsumen laki-laki lebih puas dan dalam penelitian lainnya menyatakan bahwa konsumen perempuan lebih puas dalam berbelanja online. Berdasarkan hal tersebut di atas, peneliti tertarik untuk membuktikan sendiri apakah terdapat perbedaan kepuasan kosumen mahasiswa dan mahasiswi Program Studi Psikologi Faktultas Kedokteran Universitas Udayana terhadap pelayanan online store.

\section{METODE PENELITIAN}

\section{Variabel dan Definisi Operasional}

Variabel bebas pada penelitian ini adalah jenis kelamin dan variabel terikat pada penelitian ini adalah kepuasan konsumen. Adapun definisi operasional dari kedua variabel tersebut adalah sebagai berikut:

Jenis kelamin

Jenis kelamin adalah perbedaan bentuk, sifat dan fungsi biologis, termasuk di dalamnya pembagian peran kedudukan antara laki-laki dan perempuan ditetapkan oleh masyarakat.

Kepuasan konsumen

Kepuasan konsumen adalah respon tingkat perasaan konsumen baik senang maupun sedih terhadap barang ataupun jasa layanan yang diterima dalam memenuhi kebutuhannya, dimana konsumen membandingkan antara harapan dan kenyataannya. Dengan kata lain semakin dekatnya harapan konsumen terhadap kenyataan, maka konsumen akan merasa puas dan semakin konsumen merasa puas maka konsumen akan kembali membeli barang maupun menggunakan kembali jasa layanan terdahulu. Kepuasan konsumen pada penelitian ini diukur dengan skala kepuasan konsumen yang dibuat sendiri oleh peneliti berdasarkan faktor-faktor jasa pelayanan yang memengaruhi kepuasan konsumen yang dikemukakan oleh Supranto (dalam Berata 2015).

\section{Responden}

Populasi dalam penelitian ini adalah mahasiswa aktif yang kuliah di Program Studi Psikologi FK UNUD. Sampel pada penelitian ini adalah mahasiswa yang berada di angkatan tahun 2015, tahun 2016, dan tahun 2017 di Program Studi Psikologi FK UNUD. Karakteristik sampel dalam penelitian ini antara lain, tercatat sebagai mahasiswa aktif di Program Studi Psikologi FK UNUD, memiliki pengalaman berbelanja secara online, dan bersedia mengikuti seluruh proses pengambilan data. Alasan peneliti menggunakan mahasiswa yang berada di angkatan tahun 2015, tahun 2016, dan tahun 2017 dikarenakan mahasiswa dapat digolongkan sebagai konsumen pada fase remaja akhir. Pada penelitian ini, pengambilan sampel dilakukan dengan menggunakan teknik stratified sampling. Cara pengambilan sampel dilakukan dengan merandom mahasiswa yang telah terbagi pada setiap angkatan mahasiswa yang berada di angkatan tahun 2015, tahun 2016, dan tahun 2017. Jumlah responden dalam penelitian ini adalah sebanyak 63 orang mahasiswa dan mahasiswi.

\section{Tempat penelitian}

Proses pengambilan sampel dilakukan di Program Studi Psikologi Universitas Udayana. Penelitian dilaksanakan pada bulan Mei 2018.

\section{Alat ukur}

Alat ukur yang digunakan pada penelitian ini adalah skala kepuasan konsumen. Skala kepuasan konsumen pada penelitian ini terdiri dari tujuh aspek untuk mengukur kepuasan konsumen berdasarkan kedekatan antara harapan atau ekspektasi konsumen dengan persepsi konsumen atas jasa pelayanan admin online store yang pernah konsumen gunakan dalam berbelanja online. Peneliti menyusun skala kepuasan konsumen berdasarkan faktor-faktor jasa pelayanan yang memengaruhi kepuasan konsumen yang dikemukakan oleh Supranto (dalam Berata 2015). Skala kepuasan konsumen terdiri dari 64 aitem. Model skala yang digunakan pada kedua kuesioner ini adalah skala likert dan aitem-aitem pada kuesioner terdiri dari aitem favorable serta aitem unfavorable. Pada pernyataan aitem favorable, setiap jawaban Sangat Tidak Setuju (STS) akan diberi nilai 1, Tidak Setuju (TS) akan diberi nilai 2, Setuju (S) akan diberi nilai 3, dan Sangat Setuju (SS) akan diberi nilai 4. Sedangkan dalam pernyataan aitem unfavorable, setiap jawaban Sangat Tidak Setuju (STS) akan diberi nilai 4, Tidak Setuju (TS) akan diberi nilai 3, Setuju (S) akan diberi nilai 2, dan Sangat Setuju (SS) akan diberi nilai 1.

Hasil pengujian validitas skala kepuasan konsumen menunjukkan nilai koefisien korelasi aitem-total yang berkisar dari 0,316 sampai dengan 0,784. Hasil uji reliabilitas skala kepuasan konsumen dengan menggunakan Cronbach Alpha $(\alpha)$ adalah sebesar 0,966. Berdasarkan hasil pengujian maka skala kepuasan konsumen dapat 
digunakan untuk mengukur kepuasan konsumen mahasiswa-mahasiswi terhadap pelayanan online store.

\section{Metode pengumpulan data}

Pada penelitian ini, teknik yang digunakan peneliti untuk mengumpulkan informasi dari subjek adalah dengan menggunakan skala atau kuesioner. Skala yang digunakan pada penelitian ini adalah skala kepuasan konsumen dan beberapa informasi tambahan yang tercantum pada kuesioner dan menjadi referensi penelitian ini. Setelah menentukan ketiga angkatan Program Studi Psikologi secara acak untuk digunakan sebagai sampel, peneliti menyebarkan kuesioner yang kemudian diisi oleh responden. Jumlah kuesioner yang terisi lengkap dan akan dianalisis berjumlah 63 kuesioner.

\section{Teknik analisis data}

Teknik analisis data yang digunakan dalam penelitian ini adalah uji asumsi penelitian dan uji hipotesis. Uji asumsi penelitian ini terdiri dari uji normalitas yang dilakukan dengan Kolmogorov-Smirnov dan uji homogenitas yang dilakukan dengan Independent Sample T-Test. Analisis dilakukan dengan menggunakan program spss 16.0 for windows.

\section{HASIL PENELITIAN}

\section{Uji Asumsi Penelitian}

Sebelum melakukan analisa data, data yang didapat harus mampu memenuhi dua uji asumsi yaitu uji normalitas dan uji homogenitas.

Berdasarkan uji normalitas pada tabel 1 (terlampir), nilai kolmogorov-smirnov, adalah sebesar 1.263 dengan signifikasi sebesar $0.082 \quad(\mathrm{p}>0.05)$, sehingga dapat dikatakan bahwa sebaran data pada variabel kepuasan konsumen bersifat normal.

Pada tabel 2 (terlampir) dapat dilihat bahwa hasil uji Levene Statistic memiliki tingkat signifikansi sebesar 0.930 ( $>0,05)$, sehingga dapat ditarik kesimpulan bahwa data berasal dari populasi dengan varian yang homogen.

\section{Uji Hipotesis}

Uji hipotesis dilakukan sejalan dengan tes homogenitas karena memiliki sebaran data yang homogen dan normal, yaitu dengan melihat tabel 2. Tujuan dari uji hipotesis adalah untuk mengetahui apakah terdapat perbedaan ratarata peringkat tiap kelompok penelitian. Pada tabel tersebut dapat dilihat taraf signifikasi sebesar $0.142 \quad(p>0.05)$ dengan demikian Ho diterima, yang artinya tidak terdapat perbedaan kepuasan konsumen antara mahasiswa dan mahasiswi terhadap pelayanan online store.

\section{Analisis Data Tambahan}

Penelitian ini juga memberikan data tambahan berupa kategorisasi kepuasan konsumen, deskripsi penggunaan online store, dan produk yang dibeli dari hasil analisis data yang dicantumkan pada bagian awal kuesioner penelitian. Analisis tambahan terdiri lima bagian, sebagai berikut:
Berdasarkan tabel 3 (terlampir), terlihat bahwa taraf kepuasan mahasiswa dan mahasiswi sama-sama berada pada kategori sedang. Kepuasan 8 orang mahasiswa yang berada pada kategori sedang memiliki rentang nilai diantara 142 dan 154, serta persentasenya adalah sebesar $72.73 \%$. Kepuasan 41 orang mahasiswi yang berada pada kategori sedang memiliki persentase sebesar $78.85 \%$.

Berdasarkan tabel 4 (terlampir), mahasiswa yang menggunakan online store lebih dari satu kali adalah sebanyak 10 orang $(15,87 \%)$ dan mahasiswi yang menggunakan online store lebih dari satu kali adalah sebanyak 51 orang $(80,95 \%)$, sehingga dapat disimpulkan bahwa terdapat 61 subjek penelitian yang belanja di online store atau $96,82 \%$ subjek menggunakan online store lebih dari satu kali.

Dilihat dari tabel 5 (terlampir), mahasiswa lebih banyak membeli produk yang berkaitan dengan fashion dari pada makanan atau minuman dan produk-produk kecantikan, sedangkan mahasiswi lebih banyak membeli produk kecantikan. Subjek mahasiswa memilih membeli alat-alat olahraga dan alat-alat elektronik, sedangkan subjek mahasiswi membeli buku, aksesoris handphone, dan artcraft ketika berbelanja di online store.

Berdasarkan tabel 6 (terlampir), situs Instagram merupakan situs yang paling banyak digunakan, baik subjek mahasiswa maupun subjek mahasiswi. Selain situs Instagram, situs Lazada juga diminati subjek mahasiswa dalam belanja online, karena kedua situs ini dipilih oleh masing-masing 3 orang subjek mahasiswa pada penelitian ini.

Pada tabel 7 (terlampir) dapat dilihat rangkuman hasil uji analisis T-test masing-masing indikator menunjukkan bahwa indikator ketanggapan pelayanan, indikator cara penyampaian jasa dan indikator keberadaan pelayanan memeroleh hasil yang signifikan $(\mathrm{p}<0,5)$. Hal tersebut menunjukkan bahwa subjek pada penelitian ini merasa puas dengan ketanggapan pelayanan, cara penyampaian jasa dan keberadaan pelayanan online store.

\section{PEMBAHASAN DAN KESIMPULAN}

Berdasarkan hasil analisis peneliti, tidak terdapat perbedaan kepuasan antara konsumen mahasiswa dan mahasiswi terhadap pelayanan online store. Hasil uji analisis $T$-test, menunjukkan nilai Sig atau nilai $\mathrm{P}$ sebesar $0.142>0.05$, dengan demikian Ha ditolak, yang artinya tidak terdapat perbedaan kepuasan konsumen antara terhadap pelayanan online store. Pada beberapa hasil penelitian menunjukkan bahwa terdapat perbedaan kepuasan atas pelayanan online store antara mahasiswa dan mahasiswi ditinjau berdasarkan jenis kelaminnya, sedangkan pada penelitian ini tidak terdapat perbedaan kepuasan atas pelayanan online store. Hal ini bisa saja terjadi karena hampir seluruh admin online store memiliki cara merespon yang berbeda. Penelitian ini telah 
mengkategorikan kepuasan mahasiswa dan mahasiswi berdasarkan indikator variabel kepuasan konsumen. Secara keseluruhan kepuasan konsumen mahasiswa dan mahasiswi tidak berbeda secara signifikan, yaitu samasama puas dengan pengalaman pelayanan. Tetapi apabila dikategorikan lagi pada tabel 11 sampai 17, mahasiswi cenderung lebih puas terhadap pelayanan online store yang digunakan untuk berbelanja online.

Berdasarkan hasil penelitian Lakshmi, dkk (2017), perempuan menginginkan lebih banyak interaksi, sedangkan laki-laki lebih memilih mendapat jawaban cepat. Hal ini terbukti dari indikator penelitian tentang kecepatan transaksi dan cara penyampaian jasa oleh admin online store. Mahasiswi merasa lebih puas apabila mahasiswi mengalami banyak interaksi dengan admin online store, termasuk di dalamnya tawar menawar dan konsultasi mengenai produk yang akan di beli. Beda halnya dengan mahasiswa yang cenderung lebih cepat saat bertransaksi dengan admin online store.

Selain itu, keberadaan online store mendapat tempat tersendiri dalam kedua kategori subjek penelitian ini. Hasil yang signifikan pada uji Independent Sample Test menunjukkan bahwa mahasiswa dan mahasiswi puas dengan keberadaan online store. Hal ini berbanding terbalik dengan penelitian yang dilakukan oleh Kraljevic, R. dan Filipovic, Z. (2017) yang menemukan bahwa sebagian besar pelajar universitas (mahasiswa), 57,14\% laki-laki dan $42,86 \%$ perempuan, lebih memilih membeli produk di toko dibandingkan membeli online. Keberadaan online store membuat mahasiswa dan mahasiswi lebih menghemat waktu dan diuntungkan dengan kemudahan bertransaksi.

Berdasarkan analisa peneliti pada indikator skala secara terpisah dengan menggunakan Independent Sample T-Test, peneliti menemukan bahwa indikator ketanggapan pelayanan, indikator cara penyampaian jasa, dan indikator keberadaan online store mendapatkan signifikansi tertinggi diantara indikator lainnya. Indikator ketanggapan dianggap menunjukkan kepuasan mahasiswa dan mahasiswi karena ketika konsumen mahasiswa dan mahasiswi tidak memahami deskripsi suatu produk yang dijual, admin langsung bersedia menjelaskan.

Hal tersebut secara tidak langsung dapat membangun kepercayaan (trust) konsumen. Lussyani (dalam Sutrisna, 2015) berpandangan bahwa pada bidang jasa, kepercayaan merujuk kepada sikap konsumen dalam memeroleh ketanggapan penyedia jasa dan produk yang berkualitas. Konsumen yang memiliki keyakinan pada kemampuan pelayanan yang diberikan admin online store untuk membantu konsumen dalam memenuhi kebutuhannya serta mampu menghasilkan kepuasan konsumen akan samasama memberikan keuntungan antara konsumen dan juga online store tersebut.

Cara admin menyampaikan jasa juga merupakan indikator yang dapat menjelaskan kepuasan konsumen mahasiswamahasiswi pada penelitian ini. Admin menyampaikan informasi dengan bahasa yang sopan, informatif, ramah, dengan lengkap, bahasa yang tidak kaku dan jujur. Kemampuan admin membangun kepercayaan konsumen juga merupakan salah satu alasan keberadaan online store mendapatkan hasil signifikansi yang tinggi pada penelitian ini. Gambaran kepercayaan konsumen pada penelitian ini ditunjukkan melalui kemampuan konsumen berpikir positif terhadap pelayanan yang diberikan admin online store. Admin yang berhasil membangun kepuasan pada konsumen akan otomatis mampu membangun kepercayaan konsumennya.

Pada penelitian ini terdapat 4 orang mahasiswa dan mahasiswi yang menggunakan online store hanya satu kali, dan 48 orang mahasiswa dan mahasiswi menggunakan online store untuk berbelanja adalah sebanyak lebih dari satu kali. Menurut Zeithaml dan Bitner (2005), dalam mewujudkan dan mempertahankan loyalitas pelanggan dibutuhkan tolok ukur internal SDM pada online store, identifikasi kebutuhan konsumen, dan analisis umpan balik dari pelanggan, mantan pelanggan, non-pelanggan, dan pesaing. Hal tersebut di atas yang memengaruhi harapan konsumen terhadap pelayanan online store, dan apabila terdapat online store yang tidak memperbaiki diri, maka kepuasan konsumen pun akan tetap pada kategori sedang dan menurunkan intensitas belanja online.

Selain itu, hasil analisis yang ditemukan oleh peneliti adalah bahwa terdapat sebanyak 27 orang atau sebesar $43 \%$ mahasiswa dan mahasiswi Psikologi Universitas Udayana berbelanja online melalui media Instagram. Penelitian terdahulu yang dilakukan oleh Anshari dan Rindy (2013) menyatakan bahwa Instagram merupakan aplikasi yang memudahkan penggunanya untuk mencari akun online store yaitu dengan bantuan hashtag atau tanda pagar pengait satu akun dengan akun lainnya, sehingga mahasiswa dan mahasiswi pada penelitian ini pun secara keseluruhan menggunakan Instagram sebagai media situs online store.

Penelitian ini memiliki data tambahan berupa isian singkat mengenai data dan deskripsi online store dan frekuensi menggunakan online store. Pada pengisian data terdapat isian singkat yang berisi tentang intensitas berbelanja online. Berdasarkan asumsi peneliti, subjek penelitian yang memiliki intensitas belanja online satu kali lebih sedikit dibandingkan dengan subjek yang berbelanja lebih dari satu kali. Hal ini membuktikan bahwa konsumen merasa puas dengan adanya online store, karena konsumen yang memiliki pengalaman belanja di online store dan merasa puas akan cenderung kembali berbelanja di online store. Konsumen mahasiswa dan mahasiswi pada subjek penelitian ini sama-sama puas berbelanja di online store.

Kelemahan pada penelitian ini adalah jumlah subjek yang tidak merata antara mahasiswa dan mahasiswi yang menjadi subjek pada penelitian ini. Berdasarkan hasil analisis peneliti, jumlah mahasiswa yang memilih untuk berbelanja online adalah 11 orang dari total 35 orang mahasiswa yang ada pada ketiga angkatan di Program Studi 
Psikologi Universitas Udayana atau dengan persentase $30 \%$, sedangkan jumlah mahasiswi yang memilih untuk berbelanja online adalah 52 orang dari total 104 mahasiswi yang ada pada ketiga angkatan di Program Studi Psikologi Universitas Udayana atau dengan persentase 50\%. Setelah dilakukan uji homogenitas, sebaran data penelitian ini dapat dikategorikan sebagai sebaran yang homogen. Peneliti tidak menampik fakta bahwa jumlah subjek dalam penelitian ini juga terbilang sedikit walaupun sudah memenuhi persyaratan pengambilan data, sehingga sangat berpengaruh pada hasil analisa yang menyebabkan $\mathrm{Ha}$ ditolak.

\section{DAFTAR PUSTAKA}

Aang007. (2015 November). Potensi Besar untuk Pemasukan Negara. Kominfo. Diunduh dari https://kominfo.go.id/

Alam, S., \& Yasin, M. (2008). Perkembangan teknologi Internetdi Indonesia. Teknologinet. Diunduh dari http://www.teknologinet.com/

Andriyanto. (2014 April). Perkembangan dan Sejarah Internet. Ilmuti. Diunduh dari http://ilmuti.org/wp-content/uploads/

Anshari, \& Rindy. (2013). Strategi Komunikasi Pemasaran Melalui Media Online Dan Tingkat Kepuasan Membeli (Studi Korelasional tentang Strategi Penjualan Produk Fashion melalui "Instagram" terhadap Kepuasan Membeli Mahasiswa FISIP USU). Jurnal Ilmu Komunikasi. FLOW, Vol 2 (7).

Azwar, S. (2010). Reliabilitas dan validitas. Yogyakarta: Pustaka Pelajar.

Azwar, S. (2013). Metode penelitian (Edisi ke-1). Yogyakarta: Pustaka Pelajar.

Azwar, S. (2013). Penyusunan Skala Psikologi (Edisi Ke-2). Yogyakarta: Pustaka Pelajar.

Berata, D. (2015). Faktor-Faktor Jasa Pelayanan Perbankan Yang Memengaruhi Kepuasan Konsumen Khususnya Konsumen Tabungan Pt. Bank Pembangunan Daerah Bali (Skripsi Tidak Dipublikasikan), Universitas Udayana, Bali.

Daryanto, \& Setyobudi, I. (2014). Konsumen dan pelayanan prima. Yogyakarta: Gava Media

Falakh, M., \& Wijono, S. (2016). Hubungan Antara Kualitas Pelayanan Dengan Kepuasan Konsumen Pada Villa Oase Van Java Salatiga. Skripsi Sarjana Psikologi Universitas Kristen Satya Wacana.

Hadi, S. (1991). Statistik 2. Yogyakarta : Andi Offset

Hakim, M. (2016). Kepuasan Konsumen Dalam Berbelanja Melalui $\quad$ Media Online Ditinjau Dari Jenis Kelamin. Skripsi Sarjana Psikologi Universitas Muhammadyah Malang.

Hungu. (2007). Demografi Kesehatan Indonesia. Jakarta : Grasindo

Kraljevic, R., \& Filipovic, Z. (2017). Gender Differences \& Consumer Behavior Of Millenials. Acta Economica Et Turistica, Vol. 3, (2017), No. 1, pp. 1-98

Lakshmi, V. V., Niharika, D. A., \& Lahari, G. (2017). Impact of Gender on Consumer Purchasing Behaviour. IOSR Journal of Business and Management (IOSR-JBM) e-ISSN: 2278-487X, p-ISSN: 2319-7668. Volume 19, Issue 8. Ver. V. (August 2017), PP 33-36. Diunduh dari www.iosrjournals.org
Lasmadiarta, M. (2010). Sukses Bisnis Toko Online: Trik Melipatgandakan Pasar untuk Meraup Untung Lebih Besar. Jakarta: PT Gramedia Pustaka Utama

Laudon, K. C., \& Laudon, P. J., (2000).”Organization and Technology in The Networked Enterprise" Management Information System, Six Edition, International Edition. Diunduh dari www. prenhall.com/laudon.

Mayer, R. C., Davis, J. H., \& Schoorman, F. D., (1995). An Integratif Model of Organizational Trust, Academy of Management Review [Adobe Digital Edition Version], 30 (3): 709-734.

Peter, \& Olson. (1999). Consumer Behavior and Marketing Strategy [Adobe Digital Edition Version]. Richard D. Irwan Inc, Boston. Third Edition.

Prabowo, D. (2017, Juli 15). Pusat Belanja Tak Perlu Khawatir Dengan "Online Shop". Kompas. Diunduh dari https://properti.kompas.com/read/

Pradana, M. (2015). Klasifikasi Jenis-Jenis Bisnis E-Commerce Di Indonesia. Jurnal Neo-Bis Universitas Telkom Bandung. Volume 9, No. 2, Des 2015.

Putrie, N. (2016). Perbedaan Motivasi Membeli Produk Fashion Secara Online Pada Laki-Laki Dan Perempuan Di Universitas Kristen Satya Wacana. Skripsi Sarjana Psikologi Universitas Kristen Satya Wacana.

Rahma, T., Verina, H. L., \& Hariyanto, H. S. V. (2012). Hubungan Antara Kualitas layanan Dan Harga Dengan Kepuasan Konsumen Online Shopping Pada Mahasiswi Unversitas Surabaya. Jurnal Ilmiah Mahasiswa Universitas Surabaya, 1, (1), 1-12.

Riduwan, \& Sunarto. (2011). Pengantar Statistika untuk penelitian: pendidikan, sosial, komunikasi, ekonomi, dan bisnis. Bandung: Alfabeta.

Ronaghi, M., Danae, H., Haghtalab, H. (2013). Survey of Effects of Gender on Consumer Behavior; Case Study on Mobile Phone. International Journal of Advanced Studies in Humanities and Social Science. Volume 1, Issue 8, 2013: 1024-1033. Diunduh dari http://www.ijashss.com

Sangadji, E., \& Sopiah. (2013). Perilaku Konsumen. Yogyakarta : Penerbit Andi

Santrock, W. S. (2003). Adolescence perkembangan remaja (6th ed.). Jakarta: Erlangga

Seock, Y. K., \& Sauls, N. (2008). Hispanic Consumers' Shopping Orientation

And Apparel Retail Store Evaluation Criteria, An Analysis Of Age And Gender Differences, Journal of Fashion Marketing And Management, Vol. 12 No. 4, pp.469-486.

Setiawan, R. (2004). Pengantar statistika. Yogyakarta: Pustaka Pelajar.

Setyowati, R. (2012 Oktober). Prospek Belanja "Online". Kompas. Diunduh dari https://tekno.kompas.com/read/

Sheikh, S., \& Basti, M. (2015). Customer Satisfaction in Business to Consumer (B2C) E-commerce: A Comparative Study of Turkey and Pakistan. Eurasian Journal of Business and Economics 2015, 8(16), 73-100.

Sidharta, I., \& Suzanto, B. (2015). Pengaruh Kepuasan Transaksi Online Shopping dan Kepercayaan Konsumen terhadap Sikap serta Perilaku Konsumen pada E-commerce. Jurnal Computect \& Bisnis, Vol. 9, No. 1, Juni 2015, 23-36

Solomon, M. R. (2011). Consumer Behavior : Buying, Having and Being, $9^{\text {th }}$ ed.,. New Jersey: Pearson Addison Wesley. 
Sugiyono. (2010). Metode Penelitian Pendidikan. Bandung : Alfabeta .

Sugiyono. (2013). Metode penelitian kuantitatif, kualitatif, dan kombinasi

(mixed methods). Bandung: Alfabeta.

Sugiyono. (2014). Statistika untuk penelitian. Bandung: Alfabeta.

Supangat, A. (2006). Statistika Untuk Ekonomi dan Bisnis. Bandung: Pustaka.

Sutrisna, P. B. (2015). Gambaran Kepercayaan Konsumen Dalam Berbelanja Online di FJB Kaskus (Skripsi Tidak Dipublikasikan), Universitas Udayana, Bali.

Tjiptono, F. (2005). Pemasaran jasa. Malang: Bayumedia.

Wade C., \& Tavris, C. (2007). Psikologi Jilid 1, Edisi 9. Jakarta : Erlangga.

Winarsunu, T. (2002). STATISTIK Dalam Penelitian Psikologi dan Pendidikan. Malang: Penerbitan Universitas Muhammadiyah Malang.

Wulandari, W., Sodik, \& Rahayu, Y. I. (2016). Sikap Perilaku Konsumen dalam Memutuskan Berbelanja di Pasar Tradisional Program Revitalisasi di Kota Malang (Studi Kasus Pasar Dinoyo). Seminar Nasional Inovasi dan Aplikasi Teknologi di Industri (SENIATI), 2016, ISSN : 2085-4218.

Yunita, D. (2016). Transaksi Jual Beli Melalui Media Elektronik Pada Website Online Ditinjau Dari Aspek Hukum Islam. Skripsi Sarjana Hukum Islam UIN Alauddin Makassar.

Zikra, R., \& Yusra, Z. (2016). Kepuasan Wanita Berbelanja Produk Fashion

Berdasarkan Cara Membeli. Jurnal RAP Universitas Negeri Padang, Vol. 7, No. 1, Mei 2016, hlm. 55-66. 


\section{LAMPIRAN}

Tabel 1

Hasil Uji Normalitas Variabel Penelitian

One-Sample Kolmogorov-Smirnov Test

\begin{tabular}{lc}
\hline $\mathrm{N}$ & Kepuasan konsumen \\
Kolmogorov-Smirnov Z & 63 \\
Asymp. Sig. (2-tailed) & 1.263 \\
\hline a. Test distribution is Normal. & .082 \\
\hline
\end{tabular}

\section{Tabel 2}

Hasil Uji Homogenitas Levene Test

Independent Samples Test

\begin{tabular}{|c|c|c|c|c|c|c|}
\hline & \multirow[t]{2}{*}{$\begin{array}{l}\text { Levene's Test for Equality of } \\
\text { Variances }\end{array}$} & \multicolumn{5}{|c|}{$\begin{array}{l}\text { t-test for Equality of Means } \\
95 \% \text { Confidence Interval of the Difference }\end{array}$} \\
\hline & & $\mathbf{F}$ & Sig. & $\mathbf{t}$ & df & Sig. (2-tailed) \\
\hline \multirow[t]{2}{*}{ total } & Equal variances assumed & .008 & .930 & -1.487 & 61 & .142 \\
\hline & Equal variances not assumed & & & -1.598 & 15.739 & .130 \\
\hline
\end{tabular}

Tabel 3

Kategorisasi Taraf Kepuasan Konsumen

\begin{tabular}{cccccc}
\hline \multirow{2}{*}{ Rentang Nilai } & \multirow{2}{*}{ Kategori } & \multicolumn{2}{c}{ Mahasiswa } & \multicolumn{2}{c}{ Mahasiswi } \\
\cline { 3 - 6 } & & Jumlah & Persen(\%) & Jumlah & Persen(\%) \\
\hline $\mathrm{X}<142$ & Rendah & 3 & $27.27 \%$ & 11 & $21.15 \%$ \\
$142 \leq \mathrm{X} \leq 154$ & Sedang & 8 & $72.73 \%$ & 41 & $78.85 \%$ \\
$\mathrm{X}>154$ & Tinggi & - & - & - & - \\
\hline Total & & 11 & $100 \%$ & 52 & $100 \%$ \\
\hline
\end{tabular}

Tabel 4

Frekuensi Penggunaan Online Store

\begin{tabular}{|c|c|c|c|c|c|}
\hline \multirow[b]{2}{*}{ Jenis Kelamin } & \multicolumn{4}{|c|}{ Frekuensi } & \multirow{2}{*}{$\begin{array}{c}\text { Total } \\
(\%)\end{array}$} \\
\hline & Satu Kali & Persen (\%) & $\begin{array}{c}\text { Lebih Dari } \\
\text { Satu Kali }\end{array}$ & Persen (\%) & \\
\hline Mahasiswa & 1 & $1.59 \%$ & 10 & $15.87 \%$ & $17.46 \%$ \\
\hline Mahasiswi & 1 & $1.59 \%$ & 51 & $80.95 \%$ & $82.54 \%$ \\
\hline Total & 2 & $3.18 \%$ & 61 & $96.82 \%$ & $100 \%$ \\
\hline
\end{tabular}

Tabel 5

Produk yang Dibeli Melalui Online Store

\begin{tabular}{ccccl}
\hline \multirow{2}{*}{$\begin{array}{c}\text { Jenis } \\
\text { Kelamin }\end{array}$} & $\begin{array}{c}\text { Makanan } \\
\text { atau } \\
\text { Minuman }\end{array}$ & Fashion & $\begin{array}{c}\text { Produk } \\
\text { Kecantikan }\end{array}$ & Lain-lain \\
\hline Mahasiswa & 2 & 9 & 2 & Alat Elektronik dan Alat Olahraga \\
Mahasiswi & 7 & 12 & 20 & Buku, Aksesoris Handphone dan Art Craft \\
\hline
\end{tabular}


Tabel 6

Situs Online Store yang Digunakan

\begin{tabular}{ccccccc}
\hline Jenis & \multicolumn{6}{c}{ Situs Online Store } \\
\cline { 2 - 8 } Kelamin & Instagram & Tokopedia & Bukalapak & Shopee & Lazada & Lain-lain \\
\hline Mahasiswa & 3 & 2 & 1 & 0 & 3 & PSE.com \\
\hline Mahasiswi & 24 & 6 & 1 & 8 & 7 & Zalora dan 8wood \\
\hline
\end{tabular}

Tabel 7

Kategorisasi Indikator Penggunaan Online Store

Independent Samples Test

\begin{tabular}{lccccccc}
\hline Indikator & $\mathbf{F}$ & Sig. & $\mathbf{t}$ & $\begin{array}{c}\text { df } \\
\text { Sig. (2- } \\
\text { tailed) }\end{array}$ & $\begin{array}{c}\text { Mean } \\
\text { Difference }\end{array}$ & $\begin{array}{c}\text { Std. Error } \\
\text { Difference }\end{array}$ \\
Ketanggapan Pelayanan & .775 & .381 & -1.700 & 91 & .093 & -1.477 & .869 \\
Kecepatan Transaksi & .104 & .748 & -1.396 & 91 & .166 & -1.551 & 1.111 \\
Cara Penyampaian Jasa & .549 & .461 & -1.895 & 91 & .061 & -1.950 & 1.029 \\
Profesionalisme & .157 & .693 & -1.178 & 91 & .242 & -1.710 & 1.451 \\
Bukti Pelayanan Fisik & .012 & .915 & -.047 & 91 & .963 & -.059 & 1.249 \\
$\begin{array}{l}\text { Kepuasan Menyeluruh } \\
\text { dengan Jasa }\end{array}$ & .006 & .937 & -1.396 & 91 & .166 & -1.038 & .743 \\
$\begin{array}{l}\text { Ekspektasi Keberadaan } \\
\text { Pelayanan }\end{array}$ & 2.862 & .094 & -1.228 & 91 & .223 & -.363 & .295 \\
\hline
\end{tabular}

